\title{
CORONARY EMBOLISM AND CORONARY OCCLUSION IN BACTERIAL ENDOCARDITIS
}

\author{
BY \\ BETTY WALKER \\ From the Metropolitan Hospital, London
}

\begin{abstract}
Embolic occlusion of the peripheral vessels is common in bacterial endocarditis, especially during the terminal stages, but occlusion of the coronary artery in this disease is unusual at any time.

Virchow (1856) described coronary embolism in a case of recent endocarditis. Saphir (1933) surveying earlier reports of coronary embolism from all causes, found 35 cases reported since Virchow's original paper. Of these, only 15 came to necropsy. Appelbaum and Nicholson (1934) in an analysis of the pathological anatomy of 168 cases of occlusion of the coronary arteries cited four instances of coronary embolism in bacterial endocarditis, in three of which there was recent myocardial infarction as the result. In a survey of 2877 necropsies, Levy et al. (1934) found six examples of coronary embolism, but without mentioning the source. Among 12,300 consecutive necropsies, Garvin and Work (1939) reported three cases in which bacterial endocarditis was present and in two of them myocardial infarction had taken place, although in one the coronary arteries were affected by atheroma. Lutembacher (1939) and Caplan and Alpern (1943) each described a case of coronary embolism from bacterial endocarditis producing myocardial infarction. De Navasquez (1939) examined the heart histologically in 20 unselected cases of bacterial endocarditis and found emboli resembling fragments of vegetations in 80 per cent of them. In only one was there a visible infarct. He considered that the scarcity of myocardial infarcts was due to the small size of the occluded vessels, which in his series varied from $50 \mu$ to $1.0 \mathrm{~mm}$. in diameter.

The case of bacterial endocarditis described here is of interest, not only because coronary embolism is itself uncommon but because it presents the picture of a dual mishap to the coronary circulation, namely cardiac infarction from coronary embolism and later massive ischæmia from sudden occlusion of a coronary orifice by a vegetation on the aortic cusp. Lamb (1913) described a case of occlusion of a coronary artery by a pedunculated vegetation of the aortic valve.
\end{abstract}

\section{Case Report}

A woman, aged 43 years, was admitted to hospital with loss of weight, lassitude, anorexia, and dyspnœa on exertion over a period of six months. On one or two occasions, her sputum had been streaked with blood, but until then there had been no ill health and she had never had rheumatic fever. She was pale and anæmic (hæmoglobin 40 per cent). There was fever, clubbing of the fingers, and splenomegaly, and red blood cells were found in the urine. No petechiæ or tender nodes could be found and the blood culture was repeatedly negative. Increased arterial pulsation showed in the neck; the pulse was collapsing and the blood pressure was 135/55. The apex beat was displaced outwards towards the anterior axillary line. A diastolic thrill was felt in the mitral area where presystolic and mid-diastolic murmurs of mitral stenosis were heard. An early diastolic murmur of aortic incompetence was loudest at the lower part of the left border of the sternum. There were no signs of heart failure. The electrocardiogram was normal except for bifid $P$ waves, and at cardioscopy there was moderate enlargement of the heart from aortic incompetence and mitral stenosis. The bacterial endocarditis was treated with two million units of penicillin daily for twelve weeks. 
She made satisfactory progress, but at the end of the sixth week, she experienced severe pain, constricting in character, behind the breast bone, spreading into the left shoulder and down the left arm. The blood pressure fell to $105 / 50$, but she gained relief from trinitrin in about ten minutes. An electrocardiogram (Fig. 1) taken four hours later showed a flat T wave in leads I and CR7 and an inverted $\mathrm{T}$ wave in CR4.

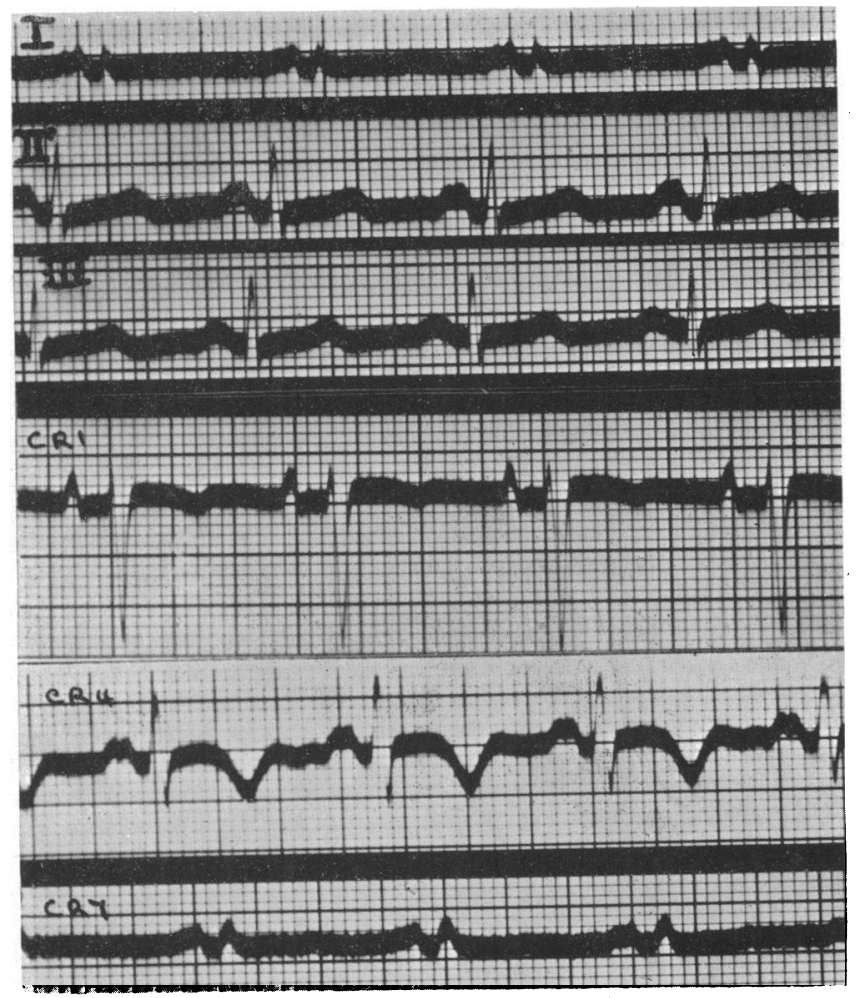

FIG. 1-Electrocardiogram taken four hours after the attack of cardiac pain. The $T$ wave is flat in leads $I$ and CR7 and is inverted in CR1 and CR4.

In view of the clinical episode and the subsequent cardiographic changes, the possibility of a coronary embolism was entertained. She had no further attacks of pain and the cardiogram remained unaltered, but seven weeks later, she sat up in bed and vomited and died unexpectedly.

Post-mortem findings. At necropsy there was an area of old fibrinous pericarditis approximately 2.5 by $1.5 \mathrm{~cm}$. on the anterior wall of the left ventricle, near the lower end of the interventricular septum. The underlying myocardium was thinned and fibrotic and there was visible infarction. The coronary arteries appeared healthy and were patent; their main branches showed no macroscopic evidence of atherosclerosis, blood clot, or embolism. The aorta was healthy. The mitral valve admitted the tip of the little finger with difficulty; it was rubbery in consistency and a few friable vegetations were present. The left atrium was moderately dilated. All three cusps of the aortic valve were thickened and almost completely destroyed and replaced by large friable vegetations, one of which measuring $1.5 \mathrm{by} 0.75 \mathrm{~cm}$. occluded the mouth of the right coronary artery (Fig. 2). The spleen was enlarged and septic and it showed infarcts, as did the kidneys.

$\mathbf{L}$ 


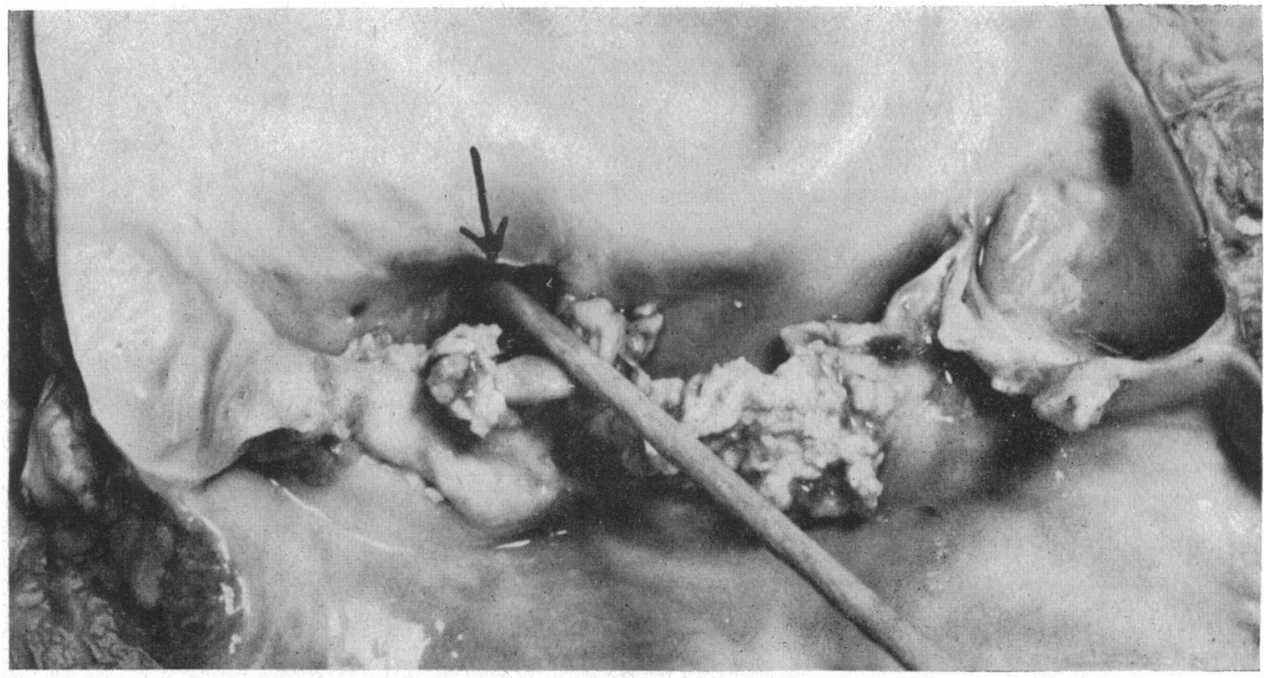

FIG. 2.-Photograph of aortic cusps and coronary ostia showing probe (marked by arrow) in right coronary artery after vegetation had been removed.

\section{Conclusion}

A patient is described in whom bacterial endocarditis affecting the aortic valve produced cardiac infarction from a coronary embolism. There was recovery from this, but sudden death took place seven weeks later from complete occlusion of the orifice of the right coronary artery by a vegetation which had spread from the adjoining aortic cusp.

I wish to express my thanks to Dr. N. G. Hulbert for his kind permission and encouragement to publish this case, and to Dr. William Evans for his valued criticism and adyice.

\section{REFERENCES}

Appelbaum, E., and Nicholson, G. H. B. (1934). Amer. Heart J., 10, 662.

Caplan, P. S., and Alpern, A. N. (1943). Pennsylvania med. J., 45, 809.

De Navasquez, S. (1939). J. Path., 49, 33.

Garvin, C. F., and Work, J. L. (1939). Amer. Heart J., 18, 747.

Lamb, A. (1913). N. Y. Path Soc., 13, 15.

Levy, R. L., Bruenn, H. G., and Kurtz, D. (1934). Amer. J. med. Sci., 187, 377.

Lutembacher, R. (1939). Pr. méd., 14, 273.

Saphir, O. (1933). Amer. Heart J., 8, 312.

Virchow, R. (1856). Virchows Arch., 9, 307. 